Original Article

\title{
Physiochemical and nutritional evaluation of whole kumquat fruits powder and its protective effect on thyroid hormones and blood sugar levels in diabetic rats
}

\author{
Avaliação físico-química e nutricional de frutas inteiras de kumquat em pó e seu \\ efeito protetor sobre os hormônios da tireoide e os níveis de açúcar no sangue em \\ ratos diabéticos
}

\author{
H. M. A. Al-Sayed ${ }^{a, b}$ (D), M. A. Abdelaleem*c (D) and H. A. Shawky (D) \\ aAin Shams University, Faculty of Agriculture, Food Science Department, Cairo, Egypt \\ 'Tabuk University, Faculty of Home Economics, Nutrition and Food Science Department, Tabuk, Saudi Arabia \\ 'Egyptian Atomic Energy Authority, Nuclear Research Center, Plant Research Department, Cairo, Egypt
}

\begin{abstract}
The present study was conducted to evaluate the chemical composition, antioxidant activity and hypoglycemic effects of whole kumquat (Ku) powder in diabetic rats fed a high-fat-high-cholesterol (HFHC) diet. The antioxidant activities were evaluated using stable 1,1-diphenyl 2-picrylhydrazyl (DPPH) free radical scavenging method, 2,2'-azinobis (3-ethyl benzo thiazoline-6-sulphonic acid) radical cation (ABTS) and Ferric reducing antioxidant power (FRAP). Total phenolic content was $(51.85 \mathrm{mg}$ GAE/g) and total flavonoid content was (0.24 mg Cateachin Equivalent, CE/g). DPPH and ABTS values were 3.32 and $3.98 \mathrm{mg}$ Trolox equivalent (TE)/g where FRAP value was $3.00 \mathrm{mM} \mathrm{Fe}^{2+} / \mathrm{kg}$ dry material. A total of 90 albino rats were used in the present study. Rats group were as follows: normal diet; normal treated $(2,4$, and $6 \% \mathrm{Ku}$.), diabetic rats (non-treated), diabetic + HFHC diet (non-treated), HFHC (non-treated), Diabetic (treated), HFHC (treated) and Diabetic + HFHC (treated). The diets were followed for 8 weeks. Blood samples were collected at the end of the experiment. Serum glucose was recorded and thyroid hormones (T4, Thyroxine and T3, Triiodothyronine) were conducted. Diet supplemented with Kumquat at different concentrations have a hypoglycemic effect and improve the thyroid hormones of both diabetic rats and HFHC diabetic rats.
\end{abstract}

Keywords: kumquat, hypoglycemia, total phenolics, total flavonoids, thyroid hormones.

\section{Resumo}

O presente estudo foi conduzido para avaliar a composição química, a atividade antioxidante e os efeitos hipoglicêmicos do pó de kumquat (Ku) em ratos diabéticos alimentados com uma dieta rica em gordura e colesterol (HFHC). As atividades antioxidantes foram avaliadas usando o método de eliminação de radicais livres de 1,1-difenil 2-picrilhidrazil (DPPH), 2,2'-azinobis (ácido 3-etilbenzotiazolina-6-sulfônico) radical cátion (ABTS) e antioxidante redutor férrico potência (FRAP). O conteúdo fenólico total foi (51,85 mg GAE / g) e o conteúdo total de flavonoides foi (0,24 mg Cateachin Equivalent, CE / g). Os valores de DPPH e ABTS foram 3,32 e 3,98 mg equivalente de Trolox (TE) / g, em que o valor de FRAP foi de 3,00 mM Fe2 + / kg de material seco. Um total de 90 ratos albinos foi usado no presente estudo. $O$ grupo dos ratos foi o seguinte: dieta normal: tratados normais ( 2,4 e $6 \%$ Ku.), ratos diabéticos (não tratados), diabéticos + dieta HFHC (não tratados), HFHC (não tratados), diabéticos (tratados), HFHC (tratados) e diabéticos + HFHC (tratados). As dietas foram seguidas por 8 semanas. Amostras de sangue foram coletadas ao final do experimento. A glicose sérica foi registrada e os hormônios tireoidianos (T4, Tiroxina e T3, Triiodotironina) foram conduzidos. A dieta suplementada com kumquat em diferentes concentrações tem um efeito hipoglicêmico e melhora os hormônios tireoidianos tanto de ratos diabéticos quanto de ratos diabéticos com HFHC.

Palavras-chave: kumquat, hipoglicemia, fenólicos totais, flavonoides totais, hormônios tireoidianos.

\section{Introduction}

Thyroid gland regulates a wide range of physiological activities such as growth, metabolism, homeostasis, and cell proliferation and differentiation through the secretion of thyroid hormones. Thyroid diseases are among the most common endocrine disorders, hypothyroidism is the most common clinical thyroid dysfunction. Hyperthyroidism

*e-mail: mdabdelrazek.md@gmail.com; abdelrazek_md@yahoo.com

Received: December 29, 2020 - Accepted: March 9, 2021 
means increased thyroid function and refers to excess metabolic state due to excessive synthesis and secretion of thyroid hormones. Medicinal plants have been identified and used by humans throughout history. The herbs and natural antioxidants are used to treat thyroid disorders including hypothyroidism and hyperthyroidism. (Shokri et al., 2018).

The main product of the thyroid gland is mainly $\mathrm{T}_{4}$ prohormone (3,5,3,5-tetraiodothyronin), also known as thyroxine, and in less amounts, $\mathrm{T}_{3}$ active hormone (3,5,3'-triiodo-L-thyronine) (Williams, 2013). Subclinical thyroid disease is defined by abnormal serum TSH, but normal $\mathrm{T}_{3}$ and $\mathrm{T}_{4}$ levels and the patients do not always need treatment, while people with clinical thyroid disease have abnormal serum $\mathrm{TSH}, \mathrm{T}_{3}$, and $\mathrm{T}_{4}$ levels and need treatment (Baskin et al., 2002).

Diabetes mellitus is a disorder that affects the body's ability to make or use insulin. Insulin is a hormone produced in the pancreas that helps transport blood glucose from the blood stream into the cells so they can break it down and use it for fuel. People cannot live without insulin. This can cause severe short-term and long-term consequences ranging from brain damage to amputations and heart disease. (American Diabetes Association, 2007). Citrus fruits have been recommended in traditional herbal medicine as the source of diabetic medication or remedy for diabetes (Baker, 1994).

Diabetes mellitus (DM) is a chronic disease which is caused either by inherited disability or acquired deficiency in production of the hormone insulin and its subsequent inability to regulate the blood glucose level and also where there is sufficient production of insulin but the insulin secreted is unable to regulate the blood glucose levels. The outcome of the above two conditions is that there is an increased level of blood glucose which in turn damages many of the vital organs (kidney, eye, etc.) of the body (Nagappa et al., 2003).

Citrus fruits are abundant in the Indian subcontinent. Lemon, lime, pomelo, sweet lime, and orange, and so forth are cultivated in abundance in different regions of India. The citrus fruits are well recognized for their various ethno-medicinal uses. These properties are attributed to their flavonoids and limonoids which are proven to possess anti-inflammatory and antitumor effects (Middleton Junior et al., 2000; Huang and Ho, 2010). The peels are rich in pectin which is known to possess blood sugar lowering and cholesterol lowering properties (Baker, 1994). Other than these, carotenoids and hydroxycinnamic acids are also abundant in citrus peels (Xu et al., 2006; Manthey and Grohmann, 2001).

Kumquat (In Chinese means golden orange) is one of the smallest citrus fruits, which is characterized by the acidic taste of flesh and soft edible peel, where the fruit can be eaten along with the peel either in the form of row fruit or as juice. It can also be used as pickles and marmalades (Chen et al., 2017). Beside the nutrients, in kumquat there are several phytochemicals in fruits including carotenoids, essential oils, ascorbic acid as well as flavonoids (Wang et al., 2012). Such phytochemicals, with various beneficial biological effects, provide kumquat a great importance as a folk medicine (Lou and Ho, 2017).
Kumquats are consumed preferably in nature, whole and in shell. It is also used to make jellies, mousse, jams, marmalades, liqueurs and cachaça, preparation of syrups, sauces and also, accompaniment salads and for landscaping purposes and ornamentation (Kawaii et al., 1999; Schirra et al., 2008). Citrus japonica has been used as a traditional folk medicine in Asian countries to reduce alcohol intoxication and as antidepressants, so they are used either as medicines or as edible fruit (Liu et al., 2018).

The objective of this study is to evaluate the physicochemical, and nutritional properties of kumquat fruits. In addition, determination the protective effect of different concentration of kumquat fruits on thyroid hormones and blood sugar levels in diabetic rats.

\section{Materials and Methods}

\subsection{Materials}

\subsubsection{Plant materials}

Fresh Kumquat fruits is obtained from the local market Cairo, Egypt. The Kumquat fruits are washed, cutting and dried at $40{ }^{\circ} \mathrm{C}$ for 2 days using air oven, then ground in laboratory mill then allowed passing through a mish sieve to obtain a fine powder of Kumquat fruits .

\subsubsection{Chemicals}

All chemical reagents were obtained from Sigma (St. Louis, MO), unless otherwise specified. All solvents used for compound isolation were HPLC grade. 2,2-diphenyl-1-picrylhydrazyl (DPPH), 6-hydroxy2,5,7,8-tetramethylchromane-2-carboxylic acid (TROLOX) and 2,2'-azino-bis (3-ethyl benzo thiazoline-6-sulphonic acid (ABTS) were purchased from Sigma-Aldrich, Germany.

\section{Methods}

\subsection{Chemical composition of kumquat fruits powder}

Chemical composition of Kumquat fruits powder including the contents of moisture, ash, crude protein and crude fat were determined according to AOAC (2007). Carbohydrates were determined by difference (as mentioned in Table 1).

\subsection{Determination of minerals}

Iron, calcium and potassium and sodium of Kumquat fruits powder were determined using atomic absorption spectrum while, phosphorus was determined by colorimeter method (ammonium molybdate) using spectrophotometer (AOAC, 2000).

\subsection{Determination of water-soluble vitamins}

An Agilent 1100 chromatographic system (Agilent Ltd., South Queensferry, UK) was used for the analysis and quantitation of water-soluble vitamins in samples according to Hasan et al. (2013). While, ascorbic acid (Vitamin C) was determined according to AOAC (2000). 
Table 1. Proximate analyses and vitamins content of whole powder Kumquat.

\begin{tabular}{|c|c|c|c|c|c|c|}
\hline & \multicolumn{6}{|c|}{ Proximate analyses } \\
\hline & Moisture (\%) & Lipids (\%) & Protein (\%) & Ash (\%) & Crude fiber (\%) & Total Carbohydrate* (\%) \\
\hline & 9.92 & 1.27 & 4.39 & 2.08 & 5.09 & 77.24 \\
\hline \multirow[t]{2}{*}{ Sugar Content $(\mathrm{g} / \mathbf{1 0 0 g})$} & \multicolumn{2}{|c|}{ Sucrose } & \multicolumn{2}{|c|}{ Glucose } & \multicolumn{2}{|r|}{ Fructose } \\
\hline & \multicolumn{2}{|c|}{35.98} & \multicolumn{2}{|c|}{13.77} & \multicolumn{2}{|r|}{14.06} \\
\hline \multirow[t]{2}{*}{$\begin{array}{l}\text { Mineral Content } \\
\quad(\mathrm{mg} / \mathbf{1 0 0 g})\end{array}$} & Ca & \multicolumn{3}{|c|}{$\mathbf{K}$} & $\mathbf{P}$ & $\mathbf{F e}$ \\
\hline & 542.64 & \multicolumn{3}{|c|}{923.35} & 140.52 & 2.28 \\
\hline \multirow{2}{*}{$\begin{array}{l}\text { Water soluble vitamins } \\
\qquad(\mathrm{mg} / \mathbf{1 0 0 g})\end{array}$} & Thiamine $\left(B_{1}\right)$ & Riboflavin $\left(B_{2}\right)$ & Niacir & Niacin $\left(B_{3}\right)$ & ocobalamin $\left(B_{12}\right)$ & Ascorbic acid (C) \\
\hline & 29.39 & 0.16 & 107 & & 9.004 & 232.60 \\
\hline
\end{tabular}

${ }^{*}$ Total carbohydrates $(\%)=100$ - sum of all proximate analyses.

\subsection{Determination of Total Phenolic Content (TPC)}

The total phenolic content of Kumquat fruits powder was determined according to the Folin-Ciocalteu procedure (Žilić et al., 2012). The total phenolic content was determined by means of a calibration curve prepared with gallic acid, and expressed as milligrams of Gallic Acid Equivalent (mg GAE) per $g$ of sample. Additional dilution was done if the absorbance value measured was over the linear range of the standard curve.

\subsection{Determination of Total Flavonoid Content (TFC)}

Total flavonoid content (TFC) of the extract of Kumquat fruits powder was determined using the aluminium chloride $\left(\mathrm{AlCl}_{3}\right)$ method according to a reliable approach using quercetin as the standard Žilić et al. (2012) The results were expressed as milligrams of Cateachin Equivalent (CE) per $g$ of dry material.

\subsection{Antioxidant activity}

\subsubsection{Determination of radical DPPH scavenging activity}

Free radical scavenging capacity of Kumquat fruits powder were determined using the stable $\mathrm{DPPH} \bullet$ according to Hwang and Thi (2014). The final concentration was $200 \mu \mathrm{M}$ for $\mathrm{DPPH} \bullet$ and the final reaction volume was $3.0 \mathrm{ml}$. The absorbance was measured at $517 \mathrm{~nm}$ against a blank of pure methanol after 60 min of incubation in a dark condition. Percent inhibition of the DPPH free radical was calculated by the following equation:

$$
\text { Inhibition } \left.(\%)=100 \times\left(A_{\text {control }}-A_{\text {sample }}\right) / A_{\text {control }}\right)
$$

Where: $A_{\text {control }}$ is the absorbance of the control reaction (containing all reagents except the test compound), $\mathrm{A}_{\text {sample }}$ is the absorbance with the test compound. The standard curve was prepared using Trolox. Results were expressed as mg Trolox equivalents (TE / g sample). Additional dilution was needed if the DPPH value measured was over the linear range of the standard.

\subsubsection{Determination of radical ABTS scavenging activity}

The stock solutions of ABTS- reagent was prepared according to Hwang and Thi (2014) by reacting equal quantities of a $7 \mathrm{mM}$ aqueous solution of ABTS- with $2.45 \mathrm{mM}$ potassium persulfate for $16 \mathrm{~h}$ at room temperature $\left(25{ }^{\circ} \mathrm{C}\right)$ in the dark. The working solution was then prepared by diluting $1 \mathrm{ml} \mathrm{ABTS}$ - solution with $60 \mathrm{ml}$ of ethanol: water $(50: 50, \mathrm{v} / \mathrm{v})$ to obtain an absorbance of $1.0 \pm 0.02$ units at $734 \mathrm{~nm}$ using the spectrophotometer. Extracts of Kumquat fruits powder $(50 \mu \mathrm{l})$ were allowed to react with $4.95 \mathrm{ml}$ of the ABTS s solution for $1 \mathrm{~h}$ in a dark condition. Then the absorbance was taken at $734 \mathrm{~nm}$ using the spectrophotometer. Percent inhibition of the ABTSfree radical was calculated by the following equation:

$$
\text { Inhibition }(\%)=100 \times\left(A_{\text {control }}-A_{\text {sample }}\right) / A_{\text {control }}
$$

Where: $A_{\text {control }}$ is the absorbance of the control reaction (containing all reagents except the test compound). $A_{\text {sample }}$ is the absorbance with the test compound. The standard curve was prepared using Trolox. Results were expressed as mg Trolox equivalents (TE / g sample). Additional dilution was needed if the ABTS• value measured was over the linear range of the standard.

\subsubsection{Ferric Reducing Activity Power (FRAP) assay}

The FRAP assay of Kumquat fruits powder was done according to Hwang and Thi (2014).

\subsection{Phenolic acids profile}

An Agilent 1100 chromatographic system equipped with an auto sampler and a diode-array detector (Agilent Ltd., South Queensferry, UK) was used for the analysis and quantitation of Phenolic acids in sample of Kumquat fruits powder according to Kim et al. (2006).

\subsection{Determination of fructose, glucose and sucrose}

The Kumquat fruits powder were mixed with $20 \mathrm{ml}$ portion of deionized water and heated to $80^{\circ} \mathrm{C}$ under magnetic stirring then sonicated for 30 minutes. The 
suspension solutions were passed through a stainless steel mesh sieves before filtering by Whatman filter paper using Buchner funnel. The final volume of solution was made up to $50 \mathrm{ml}$ and stored in refrigerator. All standards and solutions ready to analysis were passed through the $0.45 \mathrm{um}$ desk filter and sonicated for 15 minutes in ultrasonic bath. and then analysis by HPLC System (Agilent Technologies 1100 series liquid chromatograph equipped with an auto sampler and a refractive index detector) according to Salman et al. (2011).

\subsection{Biological experiment}

\subsubsection{Experimental design for biological evaluations}

A total of 90 male albino rats with an average weight of $(130: 140 \mathrm{~g})$ were purchased from the animal lab of the Research Institute of Ophthalmology, Giza, Egypt. All rats were housed in individual cages in standard conditions (Reeves et al., 1993). High-fat-High-Cholesterol (HFHC) diets (68\% control diet, 25\% palm oil, 5\% cholesterol and $2 \%$ colic acid) according to Kitamori et al. (2012). The experimental design was performed in accordance with the guide for the care and use of laboratory animals, as adopted and promulgated by the "Institutional Animal Care Committee". Blood samples were taken at the end of the experiment (49 days) for biochemical analyses (Schermer, 1967; Dhandapani et al., 2002).

\subsubsection{Induction of diabetes in rats}

Diabetic rats were induced by a single intraperitoneal injection of $45 \mathrm{mg} / \mathrm{kg}$ body weight streptozotocin (STZ) dissolved in $0.1 \mathrm{M}$ citrate buffer ( $\mathrm{pH} 4.5$ ). After 7 days of STZ injection, the tail vein blood was collected to determine fasting blood glucose level.. The STZ-treated rats were given $5 \%$ glucose water for $24 \mathrm{~h}$ following STZ injection, to prevent initial drug induced hypoglycemic mortality. Then, after 72 h STZ injection, blood was drawn from retro-orbital plexus of the surviving rats with heparinized capillaries and the fasting blood glucose levels were estimated according to a previously reported technique (Barham and Trinder, 1972). The rats with a blood glucose level of more than $250 \mathrm{mg} / \mathrm{dl}$ were regarded as experimentally induced-diabetic rats.

\subsubsection{Biochemical analysis}

All biochemical analyses were determined, by colorimetric methods as follow: glucose (Barham and Trinder, 1972), Estimation of serum T3 and T4 was estimated by enzyme-linked-immuno-sorbent-assay (ELISA) method according to Gar-Elnabi et al. (2013)

\subsection{Statistical analyses}

All the experiments were carried out in triplicate and the mean and standard error values were calculated for all data. Then, the results were subjected to one-way analysis of variance followed by Duncan's significant differences using SAS program (version 9.1.3) software (Cary, NC). Significant levels were defined as $(\mathrm{P}<0.05)$ (SAS INSTITUTE, 2004).

\section{Results and discussion}

\subsection{Proximate analysis and vitamins content of whole kumquat powder}

The proximate chemical compositions of whole dry kumquat powder are presented in Table 1 . Whole kumquat contained $9.92 \%$ moisture, $4.39 \%$ protein, $1.27 \%$ lipids, $5.09 \%$ crude fiber, $2.08 \%$ ash and $77.23 \%$ carbohydrate. As shown in Table 1 sugar types are varied in kumquat fruits where the most dominant type of sugar was sucrose $35.98 \mathrm{~g} / 100 \mathrm{~g}$. In addition, kumquats contain modest minerals contents; calcium (Ca), potassium (K), phosphorus (P) and iron (Fe) were $542.64,923.35,140.52$ and $2.28 \mathrm{mg} / 100 \mathrm{~g}$, respectively. Potassium is an important component of cell and body fluids that help to control the heart rate and blood pressure. Iron is required for red blood cell formation as well for cellular oxidation.

On the other hand, kumquat contained many types of vitamins like Thiamine (29.39 mg/100g, B1), Riboflavin (0.16 mg/100g, B2), Nisin (107.26 mg/100g, B3), Cyanocobalmin (9.004 mg/100g, B12) and Ascorbic acid (232.60 mg/100g, vitamin C). Adequate quantities of antioxidant vitamins such as vitamin C (Wang et al., 2012). Vitamin C is one powerful natural anti-oxidant, which has many essential biological roles like collagen synthesis and wound healing; anti-viral and anti-cancer activities; and helps prevent neurodegenerative diseases such as arthritis, diabetes, etc. by removing oxidant free radicals from the body. Furthermore, vitamin C facilitates iron absorption in the food by changing it from its ferrous. Collectively these phytochemical compounds in kumquat fruits help scavenge harmful oxygen derived free radicals from the body and thereby protect us from cancers, diabetes, degenerative diseases and infections. Kumquats contain good quantities of B-complex vitamins. These vitamins function as co-factors for metabolism of carbohydrates, proteins, and fats (Chambial et al., 2013).

\subsection{Antioxidant activity and total phenolics of whole kumquat}

Antioxidant activity of whole kumquat powder was evaluated using ferric reducing antioxidant power (FRAP) and DPPH free radical-scavenging assays. The FRAP and DPPH assays are simple, rapid, inexpensive tests, and are very useful as routine analyses of antioxidant activity of natural products. Table 2 showed that DPPH and ABTS were 3.32 and $3.98 \mathrm{mg} \mathrm{TE} / \mathrm{g}$, respectively. While FRAP was $3.00 \mathrm{mM} \mathrm{Fe}{ }^{2+} / \mathrm{kg}$ dry matter. Furthermore, phenolic compounds serve as antioxidants due to their free radical scavenging activity or metal chelating ability. Therefore, the high content of phenolic compounds in kumquat might result in the high antioxidant activity (Lou et al., 2014a). The total polyphenols and flavonoids of whole kumquat powder were determined and their contents were $51.85 \mathrm{mg} / \mathrm{g}$ and $0.24 \mathrm{mg} / \mathrm{g}$, respectively (Table, 2 ). Regarding the effect of heat treatment on phenolic compounds and antioxidant activity of citrus peel, Choi et al. (2011), Ho and Lin (2008), Jeong et al. (2004) and Xu et al. (2007) have been reported that high temperature drying might be used as an effective method to release bound phenolic compounds from citrus and increase their antioxidant activity. 
Table 2. Radical scavenging activity and phytochemical analysis of whole Kumquat powder.

\begin{tabular}{|c|c|c|c|}
\hline \multirow[t]{2}{*}{ Phytochemical analysis } & Total phenols (mg GAE/g) & \multicolumn{2}{|c|}{ Total flavonoids (mg CE/g) } \\
\hline & 51.85 & & 0.24 \\
\hline \multirow[t]{2}{*}{ Antioxidant activity } & DPPH (mg TE/g) & ABTS (mg TE/g) & FRAP ( $\mathrm{mM} \mathrm{Fe}^{2+} / \mathbf{k g}$ dry material $)$ \\
\hline & 3.32 & 3.98 & 3.00 \\
\hline
\end{tabular}

$\mathrm{GAE}=$ Gallic acid Equivalent; $\mathrm{CE}=$ Catechin Equivalent; $\mathrm{TE}=$ Tolorox Equivalent.

Flavonoids are very important constituents of plants because of the scavenging ability conferred by their hydroxyl groups. The flavonoids may contribute directly to anti-oxidative action. It is known that polyphenolic compounds have inhibitory effects on mutagenesis and carcinogenesis in humans when up to $1 \mathrm{~g}$ daily is consumed from a diet rich in fruits and vegetables (Tanaka et al., 1998).

Our study illustrated that the whole kumquat powder was subjected to heat treatment (drying of whole kumquat), and it concluded that high temperatures could enhance the extraction efficacy of phenolic content. In preceding studies, the antioxidant activity and total phenolic content of immature calamondin increase significantly after heat treatment at $150{ }^{\circ} \mathrm{C}$ for $1.5 \mathrm{~h}$ (Lou et al., 2014b). Thus, as shown in Table 2 our study found that the phenolic content is higher than flavonoid content as well as, a proper heat treatment could enhance the antioxidant activity of kumquat and the same trend was found by Lin et al. (2008).

The profiles of flavonoids in kumquats were quite different to citrus in which the most abundant flavonoids are naringin, hesperidin, and polymethoxy flavones, such as nobiletin and tangeretin. No nobiletin and tangeretin were found in kumquat (Lou et al., 2016). Similar data obtained by our study as shown in Table 3 where, naringeen $(50.36 \mu \mathrm{g} / \mathrm{g})$ and rosmarinic $(144.10 \mu \mathrm{g} / \mathrm{g})$ were the dominant flavonoid compounds in kumquat.

\subsection{Biological experiment}

\subsubsection{Effect of administration of whole kumquat powder on the glucose level in HFHC diabetic rats}

Many flavonoids derived from citrus fruits have been reported to reduce oxidative stress, improve glucose tolerance, insulin sensitivity and modulate lipid metabolism (Mahmoud et al., 2019). As shown in Table 4 a single intravenous injection of STZ induced an increase of fasting blood glucose levels significantly $(\mathrm{P}<0.05)$ to $358.97 \mathrm{mg} / \mathrm{dl}$ at the end of the experiment compared to the normal control $(84.24 \mathrm{mg} / \mathrm{dl})$. The blood glucose level of diabetic rats fed with a HFHC diet $(322.71 \mathrm{mg} / \mathrm{dl}$ ) was significantly $(\mathrm{P}<0.05)$ higher than those of both normal rat and HFHC rats. On the other hand, the glucose levels were always lower in HFHC-diet rats $(108.72 \mathrm{mg} / \mathrm{dl}$ ) than both diabetic rats $(358.97 \mathrm{mg} / \mathrm{dl})$ and diabetic rats fed a HFHC-diet $(322.71 \mathrm{mg} / \mathrm{dl})$.

The intraperitoneal injection of STZ at doses of $45 \mathrm{mg} / \mathrm{kg}$ into rats damages the pancreas, and insulin
Table 3. Phenolic profile of whole Kumquat powder.

\begin{tabular}{|c|c|c|c|}
\hline Compound & $\begin{array}{l}\text { Type of polyphenolic } \\
\text { compound }\end{array}$ & $T_{R}(\min )$. & $\mu \mathrm{g} / \mathrm{g}$ \\
\hline Pyrogallol & Phenolic compound & 4.7 & 459.80 \\
\hline Gallic & Phenolic compound & 5.7 & ND \\
\hline Protochatchuic & Phenolic compound & 9.9 & 22.47 \\
\hline p-hydroxybenzoic & Phenolic compound & 15.1 & 23.18 \\
\hline Gentisic & Phenolic compound & 16.8 & ND \\
\hline Catachine & Phenolic compound & 18.6 & 24.16 \\
\hline Chlorogenic & Phenolic compound & 20.6 & ND \\
\hline Caffic & Phenolic compound & 21.4 & 8.74 \\
\hline Syrngic & Phenolic compound & 23.0 & 353.08 \\
\hline Vanillic & Phenolic compound & 24.8 & ND \\
\hline Ferulic & Phenolic compound & 32.4 & 11.12 \\
\hline Sinapic & Phenolic compound & 33.8 & 112.43 \\
\hline Rutin & Phenolic compound & 36.2 & 15.34 \\
\hline p-coumaric & Phenolic compound & 37.2 & 9.09 \\
\hline Naringeen & Flavonoid compound & 38.0 & 50.36 \\
\hline Hisperdin & Flavonoid compound & 38.5 & 214.13 \\
\hline Rosmarinic & Flavonoid compound & 40.0 & 144.10 \\
\hline Cinnamic & Phenolic compound & 42.8 & 104.62 \\
\hline Qurcetin & Flavonoid compound & 43.5 & 18.10 \\
\hline Apegnin & Flavonoid compound & 46.0 & 28.45 \\
\hline Kaempferol & Flavonoid compound & 46.5 & 3.11 \\
\hline Chyrsin & Flavonoid compound & 52.0 & 4.38 \\
\hline
\end{tabular}

$\mathrm{T}_{\mathrm{R}}=$ Retention time, $\mathrm{ND}=$ Not detected.

levels typically fall to $10-30 \%$ of normal levels leading to hyperglycemia (Ozturk et al., 1996). The present results showed that long-term daily administration of whole kumquat powder significantly decreased fasting blood glucose levels in STZ-induced diabetic rats. These obtained data are in agreement with Tan et al. (2014) who found that kumquat extract reduced blood sugar levels and insulin resistance in diabetic and obese mice. The antihyperglycemic effect of kumquat might be due to simulation of insulin release, like results obtained by Singab et al. (2005) who mentioned that up to different hypotheses of ability of mulberry induced lowering fasting blood glucose level in diabetic rats is probably due to stimulation of insulin release. 


\subsubsection{Effect of administration of whole kumquat powder on the thyroid hormones in HFHC diabetic rats}

Thyroid hormones thyroxine (T4) and triiodothyronine (T3) are tabulated in Table 5. The present data showed that the T3 and T4 hormones were significantly $(\mathrm{P}<0.05)$ decreased in diabetic control (51.56 and $3.08 \mathrm{ng} / \mathrm{dl}$ ) compared to normal group ( 85.86 and $5.63 \mathrm{ng} / \mathrm{dl}$ ). As mentioned before in Table 4, where the fasting blood glucose level was elevated up to $358.97 \mathrm{mg} / \mathrm{dl}$ in diabetic non treated group. Thus, the higher the level of fasting blood glucose occurs, the lower the thyroid hormones are founded.

Table 4. Effect of administration whole kumquat powder on blood glucose levels in diabetic rats fed on high-fat / high-cholesterol.

\begin{tabular}{|c|c|c|c|}
\hline & \multicolumn{3}{|c|}{ Glucose concentration (mg/dl) } \\
\hline & \multicolumn{3}{|c|}{ Non-treated with Kumquat (0\% Kumquat) } \\
\hline Normal & \multicolumn{3}{|c|}{$84.24^{b} \pm 3.81$} \\
\hline Diabetic & \multicolumn{3}{|c|}{$358.97^{\mathrm{g}} \pm 4.03$} \\
\hline HFHC & \multicolumn{3}{|c|}{$108.92^{\mathrm{c}} \pm 3.74$} \\
\hline \multirow{3}{*}{$\begin{array}{c}\text { Diabetic + } \\
\text { HFHC }\end{array}$} & \multicolumn{3}{|c|}{$322.71^{\mathrm{f}} \pm 4.25$} \\
\hline & \multicolumn{3}{|c|}{ Treated with Kumquat } \\
\hline & 2\% Kumquat & 4\% Kumquat & 6\% Kumquat \\
\hline Normal & $101.12^{\mathrm{c}} \pm 3.76$ & $82.59^{\mathrm{ab}} \pm 3.93$ & $84.99^{\mathrm{b}} \pm 4.07$ \\
\hline Diabetic & $144.52^{\mathrm{d}} \pm 2.36$ & $143.17^{\mathrm{d}} \pm 3.54$ & $141.68^{\mathrm{d}} \pm 4.26$ \\
\hline HFHC & $74.70^{\mathrm{ab}} \pm 4.03$ & $70.85^{\mathrm{a}} \pm 4.31$ & $79.94^{\mathrm{ab}} \pm 4.35$ \\
\hline $\begin{array}{c}\text { Diabetic + } \\
\text { HFHC }\end{array}$ & $185.71^{\mathrm{e}} \pm 4.11$ & $178.32^{\mathrm{e}} \pm 4.46$ & $134.82^{\mathrm{d}} \pm 4.13$ \\
\hline
\end{tabular}

HFHC = High-fat-High-cholesterol; Each value represents the mean \pm Standard Error (S.E.), The mean value with different superscript alphabets indicate significant differences $(\mathrm{P}<0.05)$ using Duncan test.
Thyroid gland plays a central role in the regulation of metabolism. So, abnormal thyroid function can have a major impact on the control of diabetes. Besides, untreated thyroid disorder can increase the risk of certain diabetic complications and can aggravate many diabetes symptoms. The effect of the thyroid hormones (T3 and T4) on metabolism and the major organ systems of the human body appears in stimulating the enzymes concerned with glucose oxidation and enhancing the rate of uptake of glucose, affecting synthesis, mobilization and degradation of lipids, and lowering blood cholesterol (Idris, 2011).

Thyroid hormones act directly in the insulin secretion. In the hypothyroidism condition there is an increase of insulin secretion stimulated by glucose in the cells, and the opposite occurs in the hyperthyroidism condition, reducing the secretion of insulin stimulated by glucose (Mitrou et al., 2010; Stanická et al., 2005). Comte et al. (1990) reported that the reduction of gluconeogenesis caused hypothyroidism. Thus the mode of action, as herbal powder and extracts reduced higher levels of thyroid hormones in diabetic rats, this is due to the reduction of gluconeogenesis which led to a reduction in thyroid hormones leading to hypothyroidism (but not vice versa). Regarding the levels thyroid hormones T3 (72.12 ng/dl ) and T4 (4.67 ng/dl ) in HFHC non-treated diabetic rats, the administration of HFHC diet during the study revealed that significantly $(\mathrm{P}<0.05)$ decrement of the thyroid hormones compared to normal rats.

Therefore, it could be concluded that the increase in glucose level led to a reduction in thyroid hormones. More important, hypothyroidism is accompanied by a variety of abnormalities in blood lipid levels. This includes increased total cholesterol and LDL (low-density lipoprotein or "bad") cholesterol levels, and increased triglyceride levels. The abnormal lipid pattern typical of Type 2 diabetes (low HDL, or "good" cholesterol, high triglycerides, and a high proportion of small, dense LDL particles) is usually worsened by hypothyroidism. These changes further raise the already high risk of cardiovascular diseases such as heart disease and stroke among people with diabetes.

Table 5. Effect of administration whole kumquat powder on thyroid hormones $\left(\mathrm{T}_{3}\right.$ and $\left.\mathrm{T}_{4}\right)$ in diabetic rats fed on high-fat / high-cholesterol.

\begin{tabular}{|c|c|c|c|c|c|c|}
\hline & \multicolumn{3}{|c|}{$\mathrm{T}_{3}(\mathrm{ng} / \mathrm{dl})$} & \multicolumn{3}{|c|}{$\mathrm{T}_{4}(\mathrm{ng} / \mathrm{dl})$} \\
\hline & \multicolumn{3}{|c|}{ Non-treated with Kumquat (0\% Kumquat) } & \multicolumn{3}{|c|}{ Non-treated with Kumquat (0\% Kumquat) } \\
\hline Normal & \multicolumn{3}{|c|}{$85.86^{\mathrm{de}} \pm 1.35$} & \multicolumn{3}{|c|}{$5.63^{\mathrm{f}} \pm 0.12$} \\
\hline Diabetic & \multicolumn{3}{|c|}{$51.56^{a} \pm 1.07$} & \multicolumn{3}{|c|}{$3.08^{\mathrm{a}} \pm 0.07$} \\
\hline HFHC & \multicolumn{3}{|c|}{$87.06^{\mathrm{de}} \pm 2.13$} & \multicolumn{3}{|c|}{$5.46^{\mathrm{ef}} \pm 0.08$} \\
\hline \multirow[t]{3}{*}{ Diabetic + HFHC } & \multicolumn{3}{|c|}{$72.12^{\mathrm{c}} \pm 7.06$} & \multicolumn{3}{|c|}{$4.67^{b} \pm 0.09$} \\
\hline & \multicolumn{3}{|c|}{ Treated with Kumquat } & \multicolumn{3}{|c|}{ Treated with Kumquat } \\
\hline & 2\% Kumquat & 4\% Kumquat & 6\% Kumquat & 2\% Kumquat & 4\% Kumquat & $6 \%$ Kumquat \\
\hline Normal & $91.74^{\mathrm{ef}} \pm 0.86$ & $94.66^{\mathrm{f}} \pm 1.63$ & $91.92^{\mathrm{ef}} \pm 2.66$ & $5.18^{\mathrm{de}} \pm 0.16$ & $5.29^{\mathrm{def}} \pm 0.14$ & $5.21^{\text {de }} \pm 0.12$ \\
\hline Diabetic & $74.82^{\mathrm{c}} \pm 1.79$ & $75.13^{\circ} \pm 1.62$ & $76.23^{\mathrm{c}} \pm 1.89$ & $4.52^{b} \pm 0.13$ & $4.72^{\mathrm{b}} \pm 0.14$ & $4.78^{\mathrm{bc}} \pm 0.11$ \\
\hline HFHC & $82.58^{\mathrm{d}} \pm 2.79$ & $89.03^{\mathrm{def}} \pm 3.04$ & $92.44^{\mathrm{ef}} \pm 1.41$ & $5.08^{\mathrm{cd}} \pm 0.06$ & $5.51^{\mathrm{ef}} \pm 0.12$ & $5.97^{\mathrm{g}} \pm 0.15$ \\
\hline Diabetic + HFHC & $49.12^{\mathrm{a}} \pm 2.66$ & $59.80^{\mathrm{b}} \pm 1.88$ & $88.65^{\text {def }} \pm 0.77$ & $4.54^{b} \pm 0.05$ & $4.64^{b} \pm 0.13$ & $5.46^{\mathrm{ef}} \pm 0.14$ \\
\hline
\end{tabular}

$\mathrm{T}_{3}=$ Triiodothyronine; $\mathrm{T}_{4}=$ Thyroxine; $\mathrm{HFHC}=$ High-fat/High-cholesterol; Each value under the certain hormone represents the mean \pm Standard Error (S.E.): The mean value with different superscript alphabets indicate significant differences $(\mathrm{P}<0.05)$ using Duncan test. 
Another explanation of the reduction of the thyroid hormones (T3 and T4), is the possibilities include caffeic acid phenyl ester induced modulation in de-iodination system, which affects de-iodinase activity through its antioxidant properties (Brzezi ska-Slebodzi ska, 2001; Vrca et al., 2004).

Due to kumquat is a rich source of phytochemicals (flavonoids and phenolic acids) which caused antioxidative activity, it has anti-thyroidal properties, which suggest its potential to ameliorate hyperthyroidism. Same results are found by Chandra and De (2014). The anti-thyroidal role of might be mediated through the inhibition of thyroid peroxidase the key enzyme in thyroid hormone biosynthesis (Cooksey et al., 1986), as it contains the phenolic compound naringin, which inhibits the activity of thyroid peroxidas. Thus, the administration of whole kumquat powder in treated rats, caused hypoglycemic effect in diabetic rats then led to increase the T3 and T4 hormones.

\section{Conclusion}

Using natural products like kumquat as protective effect on thyroid hormones and blood sugar levels in high-fathigh-cholesterol diabetic rats. Our study concludes that the whole kumquat elevate serum concentration of T3 and T4 in HFHC diabetic rats at the doses of $2 \%$ to $6 \%$ showing a strong antithyroidal effect. However, we emphasize that further studies are required to identify the precise mechanism of action and isolation of active principle (s) responsible for such activities.

\section{References}

AMERICAN DIABETES ASSOCIATION, 2007. Diagnosis and classification of diabetes mellitus. Diabetes Care, vol. 30, no. suppl. 1, pp. S42-S47. PMid:17192378.

ASSOCIATION OF OFFICIAL ANALYTICAL CHEMISTS - AOAC, 2000. Official Methods of Analysis of AOAC International. 17th ed. Rockville: AOAC International.

ASSOCIATION OF OFFICIAL ANALYTICAL CHEMISTS - AOAC, 2007. Official Methods of Analysis of AOAC International. 18th ed. Rockville: AOAC International.

BAKER, R.A., 1994. Potential dietary benefits of citrus pectin and fiber. Food Technology, vol. 48, no. 11, pp. 133-138.

BARHAM, D. and TRINDER, P., 1972. An improved colour reagent for the determination of blood glucose by the oxidase system. Analyst, vol. 97, no. 1151, pp. 142-145. http://dx.doi.org/10.1039/ an9729700142. PMid:5037807.

BASKIN, H.J., COBIN, R.H., DUICK, D.S., GHARIB, H., GUTTLER, R.B., KAPLAN, M.M., SEGAL, R.L., GARBER, J.R., HAMILTON JUNIOR, C.R., HANDELSMAN, Y., HELLMAN, R., KUKORA, J.S., LEVY, P., PALUMBO, P.J., PETAK, S.M., RETTINGER, H.I., RODBARD, H.W., SERVICE, F.J., SHANKAR, T.P., STOFFER, S.S. and TOURTELOT, J.B., 2002. American association of clinical endocrinologists medical guidelines for clinical practice for the evaluation and treatment of hyperthyroidism and hypothyroidism. Endocrine Practice, vol. 8, no. 6, pp. 457-469. http://dx.doi. org/10.4158/1934-2403-8.6.457.

BRZEZI SKA-SLEBODZI SKA, E., 2001. Fever induced oxidative stress: the effect on thyroid status at the 5 -monodeiodinase activity, protective role of selenium and vitamin E. Journal of Physiology and Pharmacology, vol. 52, no. 2, pp. 275-284. PMid:11453106.

CHAMBIAL, S., DWIVEDI, S., SHUKLA, K.K., JOHN, P.J. and SHARMA, P., 2013. Vitamin C in disease prevention and cure: an overview. Indian Journal of Clinical Biochemistry, vol. 28, no. 4, pp. 314-328. http://dx.doi.org/10.1007/s12291-013-0375-3. PMid:24426232.

CHANDRA, A.K. and DE, N., 2014. Goitrogenic and antithyroid potential of green tea of Indian origin. Journal of Bangladesh Society of Physiologist, vol. 9, no. 2, pp. 105-116. http://dx.doi. org/10.3329/jbsp.v9i2.22807.

CHEN, M.H., YANG, K.M., HUANG, T.C. and WU, M.L., 2017. Traditional small-size citrus from Taiwan: essential oils, bioactive compounds and antioxidant capacity. Medicines, vol. 4, no. 2, pp. 28. http://dx.doi.org/10.3390/medicines 4020028. PMid:28930243.

CHOI, M.Y., CHAI, C., PARK, J.H., LIM, J., LEE, J. and KWON, S.W., 2011. Effects of storage period and heat treatment on phenolic compound composition in dried citrus peels (Chenpi) and discrimination of Chenpi with different storage periods through targeted metabolomic study using HPLC-DAD analysis. Journal of Pharmaceutical and Biomedical Analysis, vol. 54, no. 4, pp. 638-645. http://dx.doi.org/10.1016/j.jpba.2010.09.036. PMid:21145683.

COMTE, B., VIDAL, H., LAVILLE, M. and RIOU, J.P., 1990. Influence of thyroid hormones on gluconeogenesis from glycerol in rat hepatocytes: a dose-response study. Metabolism: Clinical and Experimental, vol. 39, no. 3, pp. 259-263. http://dx.doi. org/10.1016/0026-0495(90)90044-D. PMid:2308516.

COOKSEY, R.C., LINDSAY, R.H., GAITAN, E., HILL, J. and REICHERT, R.D., 1986. Intrathyroidal effects of flavonoids. American Chemical Society, vol. 26, pp. 75.

DHANDAPANI, S., SUBRAMANIAN, V. R., RAJAGOPAL, S. and HYPOLIPDIMIC, N. N., 2002. Effect of Cuminum cyminum L. on alloxan-induced diabetic rats. Phamacological research, vol. 46, no. 3, pp. 251-255.

GAR-ELNABI, M.E.M., TAHA, R.M., ALIOMER, M., FARAHNA, M. and BUSHARA, Y.M., 2013. Assessment of human thyroid function using radioimmunoassay and enzyme-linked immuno-sorbentassay. Journal of Experimental and Clinical Medicine, vol. 30, no. 4, pp. 317-321. http://dx.doi.org/10.5835/jecm.omu.30.04.007.

HASAN, M.N., AKHTARUZZAMAN, M. and SULTAN, M.Z., 2013. Estimation of vitamins B-complex (B2, B3, B5 and B6) of some leafy vegetables indigenous to Bangladesh by HPLC method. Journal of Analytical Sciences, vol. 3, pp. 24-29.

HO, S.C. and LIN, C.C., 2008. Investigation of heat treating conditions for enhancing the anti-inflammatory activity of citrus fruit (Citrus reticulate) peels. Journal of Agricultural and Food Chemistry, vol. 56, no. 17, pp. 7976-7982. http://dx.doi. org/10.1021/jf801434c. PMid: 18683945.

HUANG, Y.S. and HO, S.C., 2010. Polymethoxy flavones are responsible for the anti-inflammatory activity of citrus fruit peel. Food Chemistry, vol. 119, no. 3, pp. 868-873. http://dx.doi. org/10.1016/j.foodchem.2009.09.092.

HWANG, E. and THI, N.D., 2014. Effects of extraction and processing methods on antioxidant compound contents and radical scavenging activities of laver (Porphyra tenera). Preventive Nutrition and Food Science, vol. 19, no. 1, pp. 40-48. http://dx.doi. org/10.3746/pnf.2014.19.1.040. PMid:24772408.

IDRIS, A.S., 2011. Effect of some natural products on the level of thyroid related hormones in rats. Sudan: Sudan Academy of Sciences, SAS Atomic Energy Council, 55 p. MSc Thesis. 
JEONG, S.M., KIM, S.Y., KIM, D.R., JO, S.C., NAM, K.C., AHN, D.U and LEE, S., 2004. Effect of heat treatment on the antioxidant activity of extracts from citrus peels. Journal of Agricultural and Food Chemistry, vol. 52, no. 11, pp. 3389-3393. http://dx.doi. org/10.1021/jf049899k. PMid:15161203.

KAWAII, S., TOMONO, Y., KATASE, E., OGAWA, K. and YANO, M., 1999. Quantitation of flavonoid constituents in citrus fruits. Journal of Agricultural and Food Chemistry, vol. 47, no. 9, pp. 3565-3571. http://dx.doi.org/10.1021/jf990153+. PMid:10552686.

KIM, K., TSAO, R., YANG, R. and CUI, S.W., 2006. Phenolic acid profiles and antioxidant activities of wheat bran extracts and the effect of hydrolysis conditions. Food Chemistry, vol. 95, no. 3 , pp. 466-473. http://dx.doi.org/10.1016/j.foodchem.2005.01.032.

KITAMORI, K., NAITO, H., TAMADA, H., KOBAYASHI, M., MIYAZAWA, D., YASUI, Y., SONODA, K., TSUCHIKURA, S., YASUI, N., IKEDA, K., MORIYA, T., YAMORI, Y. and NAKAJIMA, T., 2012. Development of novel rat model for high-fat and high-cholesterol diet-induced steatohepatitis and severe fibrosis progression in SHRSP5/Dmcr. Environmental Health and Preventive Medicine, vol. 17, no. 3, pp. 173-182. http://dx.doi.org/10.1007/s12199-011-0235-9. PMid:21853259.

LIN, C.C., HUNG, P.F. and HO, S.C., 2008. Heat treatment enhances the NO-suppressing and peroxynitrite-intercepting activities of kumquat (Fortunella margarita Swingle) peel. Food Chemistry, vol. 109, no. 1, pp. 95-103. http://dx.doi.org/10.1016/j. foodchem.2007.12.053. PMid:26054269.

LIU, Y., LIU, Y., LIU, Y., LIU, H. and SHANG, Y., 2018. Evaluating effects of ellagic acid on the quality of kumquat fruits during storage. Scientia Horticulturae, vol. 227, pp. 244-254. http:// dx.doi.org/10.1016/j.scienta.2017.08.055.

LOU, S.N. and HO, C.T., 2017. Phenolic compounds and biological activities of small-size citrus: kumquat and calamondin. Journal of Food and Drug Analysis, vol. 25, no. 1, pp. 162-175. PMid:28911534.

LOU, S.N., HSU, Y.S. and HO, C.T., 2014a. Flavonoid compositions and antioxidant activity of calamondin extracts prepared using different solvents. Journal of Food and Drug Analysis, vol. 22, no. 3, pp. 290-295. PMid:28911417.

LOU, S.N., LAI, Y.C., HSU, Y.S. and HO, C.T., 2016. Phenolic content, antioxidant activity and effective compounds of kumquat extracted by different solvents. Food Chemistry, vol. 197, no. A, pp. 1-6. http://dx.doi.org/10.1016/j.foodchem.2015.10.096. PMid:26616917.

LOU, S.N., LIN, Y.S., HSU, Y.S., CHIU, E.M. and HO, C.T., 2014b. Soluble and insoluble phenolic compounds and antioxidant activity of immature calamondin affected by solvents and heat treatment. Food Chemistry, vol. 161, pp. 246-253. http://dx.doi.org/10.1016/j. foodchem.2014.04.009. PMid:24837947.

MAHMOUD, A.M., HERNÁNDEZ BAUTISTA, R.J., SANDHU, M.A. and HUSSEIN, O.E., 2019. Beneficial effects of citrus flavonoids on cardiovascular and metabolic health. Oxidative Medicine and Cellular Longevity, vol. 2019, pp. 5484138. http://dx.doi. org/10.1155/2019/5484138. PMid:30962863.

MANTHEY, J.A. and GROHMANN, K., 2001. Phenols in citrus peel byproducts. Concentrations of hydroxycinnamates and polymethoxylated flavones in citrus peel molasses. Journal of Agricultural and Food Chemistry, vol. 49, no. 7, pp. 3268-3273. http://dx.doi.org/10.1021/jf010011r. PMid:11453761.

MIDDLETON JUNIOR, E., KANDASWAMI, C. and THEOHARIDES, T.C., 2000. The effects of plant flavonoids on mammalian cells: implications for inflammation, heart disease, and cancer. Pharmacological Reviews, vol. 52, no. 4, pp. 673-751. PMid:11121513.
MITROU, P., RAPTIS, S.A. and DIMITRIADIS, G., 2010. Insulin action in hyperthyroidism: a focus on muscle and adipose tissue. Endocrine Reviews, vol. 31, no. 5, pp. 663-679. http://dx.doi. org/10.1210/er.2009-0046. PMid:20519325.

NAGAPPA, A.N., THAKURDESAI, P.A., RAO, N.V. and SINGH, J., 2003. Antidiabetic activity of Terminalia catappa Linn fruits. Journal of Ethnopharmacology, vol. 88, no. 1, pp. 45-50. http://dx.doi. org/10.1016/S0378-8741(03)00208-3. PMid:12902049.

OZTÜRK, Y., ALTAN, V.M. and YILDIZOGLU-ARI, N., 1996. Effects of experimental diabetes and insulin on smooth muscle functions. Pharmacological Reviews, vol. 48, no. 1, pp. 69-112. PMid:8685248.

REEVES, P.G., NIELSEN, F.H. and FAHEY JUNIOR, G.C., 1993. AIN93 purified diets for laboratory rodents: final report of the American Institute of Nutrition ad hoc writing committee on the reformulation of the AIN-76A rodent diet. The Journal of Nutrition, vol. 123, no. 11, pp. 1939-1951. http://dx.doi. org/10.1093/jn/123.11.1939. PMid:8229312.

SALMAN M., ALGHAMDI M. T., BAZAID S. A. and ABDEL-HAMEED E.S., 2011. Determination of fructose, glucose and sucrose in taif grape using high performance liquid chromatography and analysis of mineral salts. Archives of Applied Science Research, vol. 3, no. 6, pp. 488-496.

SAS INSTITUTE, 2004. SAS user's guide release 6.0. 4th ed. Cary: SAS Institute.

SCHERMER, S., 1967. The blood morphology of laboratory animals. Philadelphia: Davis.

SCHIRRA, M., PALMA, A., D’AQUINO, S., ANGIONI, A., MINELLO, E.V., MELIS, M. and CABRAS, P., 2008. Influence of postharvest hot water treatment on nutritional and functional properties of kumquat (Fortunella japonica Lour. Swingle Cv.Ovale) fruit. Journal of Agricultural and Food Chemistry, vol. 56, no. 2, pp. 455-460. http://dx.doi.org/10.1021/jf0714160. PMid:18163539.

SHOKRI, Z., KHOSHBIN, M., KOOHPAYEH, A., ABBASI, N., BAHMANI, F., RAFIEIAN-KOPAEI, M. and FATEMEH, B., 2018. Thyroid diseases: pathophysiology and new hopes in treatment with medicinal plants and natural antioxidants. International Journal of Green Pharmacy, vol. 12, no. 3, pp. S473-S482.

SINGAB, A.N., EL-BESHBISHY, H.A., YONEKAWA, M., NOMURA, T. and FUKAI, T., 2005. Hypoglycemic effect of Egyptian Morus alba root bark extract: effect on diabetes and lipid peroxidation of streptozotocininduced diabetic rats. Journal of Ethnopharmacology, vol. 100, no. 3, pp. 333-338. http://dx.doi. org/10.1016/j.jep.2005.03.013. PMid:15885940.

STANICKÁ, S., VONDRA, K., PELIKÁNOVÁ, T., VLČEK, P., HILL, M. and ZAMRAZIL, V., 2005. Insulin sensitivity and counterregulatory hormones in hypothyroidism and during thyroid hormone replacement therapy. Clinical Chemistry and Laboratory Medicine, vol. 43, no. 7, pp. 715-720. http://dx.doi.org/10.1515/ CCLM.2005.121. PMid:16207130.

TAN, S., LI, M., DING, X., FAN, S., GUO, L., GU, M., ZHANG, Y., FENG, L., JIANG, D., LI, Y., XI, W., HUANG, C. and ZHOU, Z., 2014. Effects of Fortunella margarita fruit extract on metabolic disorders in high-fat diet-induced obese C57BL/6 mice. PLoS One, vol. 9, no. 4, pp. e93510. http://dx.doi.org/10.1371/journal.pone.0093510. PMid:24705395.

TANAKA, M., KUEI, C.W. and NAGASHIMA, Y., 1998. Application of Antioxidative maillrad reaction products from histidine and glucose to sardine products. Nippon Suisan Gakkaishi, vol. 47, pp. 1409-1414.

VRCA, V.B., SKREB, F., CEPELAK, I., ROMIC, Z. and MAYER, L., 2004. Supplementation with antioxidants in the treatment of Graves' disease, the effect on glutathione peroxidase activity and 
concentration of selenium. Clinica Chimica Acta, vol. 341, no. 1-2, pp. 55-63. http://dx.doi.org/10.1016/j.cccn.2003.10.028. PMid: 14967159.

WANG, Y., ZENG, W., XU, P., LAN, Y., ZHU, R., ZHONG, K., HUANG, Y. and GAO, H., 2012. Chemical composition and antimicrobial activity of the essential oil of kumquat (Fortunella crassifolia Swingle). International Journal of Molecular Sciences., vol. 13, no. 3, pp. 3382-3393. http://dx.doi.org/10.3390/ijms13033382. PMid:22489157.

WILLIAMS, G.R., 2013. Thyroid hormone actions in cartilage and bone. European Thyroid Journal, vol. 2, no. 1, pp. 3-13. http:// dx.doi.org/10.1159/000345548. PMid:24783033.

XU, C.J., FRASER, P.D., WANG, W.J. and BRAMLEY, P.M., 2006. Differences in the carotenoid content of ordinary citrus and lycopene-accumulating mutants. Journal of Agricultural and
Food Chemistry, vol. 54, no. 15, pp. 5474-5481. http://dx.doi. org/10.1021/jf060702t. PMid:16848534.

XU, G., YE, X.G., CHEN, J.C. and LIU, D.H., 2007. Effect of heat treatment on the phenolic compounds and antioxidant capacity of citrus peel extract. Journal of Agricultural and Food Chemistry, vol. 55, no. 2, pp. 330-335. http://dx.doi.org/10.1021/jf062517l. PMid:17227062.

ŽILIĆ, S., SERPEN, A., AKILLIOĞLUC, G., JANKOVIĆ, M. and GÖKMENBC, V., 2012. Distributions of phenolic compounds, yellow pigments and oxidative enzymes in wheat grains and their relation to antioxidant capacity of bran and debranned flour. Journal of Cereal Science, vol. 56, no. 3, pp. 652-658. http://dx.doi. org/10.1016/j.jcs.2012.07.014. 